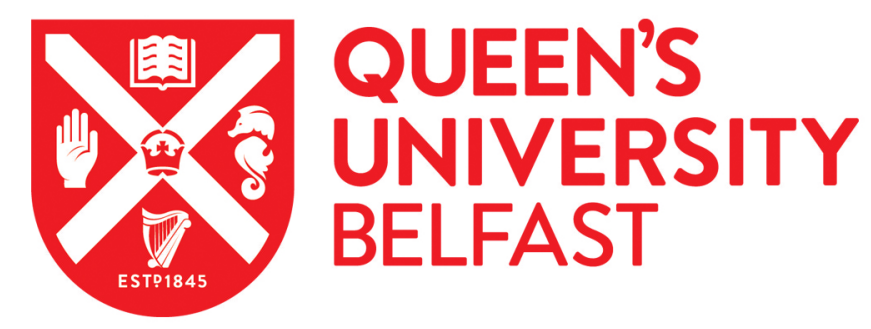

\title{
Twenty years of research on community composition and species distribution of arbuscular mycorrhizal fungi in China: A review
}

Gai, J. P., Christie, P., Feng, G., \& Li, X. L. (2006). Twenty years of research on community composition and species distribution of arbuscular mycorrhizal fungi in China: A review. Mycorrhiza, 16(4), 229-239. https://doi.org/10.1007/s00572-005-0023-8

Published in:

Mycorrhiza

Queen's University Belfast - Research Portal:

Link to publication record in Queen's University Belfast Research Portal

\section{General rights}

Copyright for the publications made accessible via the Queen's University Belfast Research Portal is retained by the author(s) and / or other copyright owners and it is a condition of accessing these publications that users recognise and abide by the legal requirements associated with these rights.

Take down policy

The Research Portal is Queen's institutional repository that provides access to Queen's research output. Every effort has been made to ensure that content in the Research Portal does not infringe any person's rights, or applicable UK laws. If you discover content in the Research Portal that you believe breaches copyright or violates any law, please contact openaccess@qub.ac.uk. 


\section{Twenty years of research on community composition and species distribution of arbuscular mycorrhizal fungi in China: a review}

Received: 6 April 2005 / Accepted: 21 September 2005 / Published online: 6 May 2006

C) Springer-Verlag 2006

\begin{abstract}
The biodiversity and distribution of arbuscular mycorrhizal fungi (AMF) in different ecosystems and plant communities in China has received increasing interest over the past decades. This has led to a steady increase in the number of scientific papers published on this topic. Studies have surveyed AMF-colonizing rhizospheres of most families of angiosperms, bryophytes, pteridophytes, and gymnosperms. China has about 30,000 plant species (one eighth of the plant species worldwide). A total of 104 AMF species within nine genera, including 12 new species, have been reported in environments such as croplands, grasslands, forests, and numerous disturbed environments. In this paper, we review data published over the past 20 years on AMF community composition and species distribution, the mycorrhizal status of plants, AMF spore communities in different habitats, and germplasm collections in China. Possible future trends in the study of the biodiversity of AMF are also briefly discussed. In particular, the aim of our review is to make some of the recent work published in the Chinese literature accessible to a wider international audience.
\end{abstract}

Keywords Arbuscular mycorrhizal fungi - Biogeography · China $\cdot$ Species richness $\cdot$ Vegetation diversity

J. P. Gai · P. Christie · G. Feng · X. L. Li ( ()

Department of Plant Nutrition,

China Agricultural University,

2 Yuanmingyuan Road,

Beijing, 100094, People's Republic of China

e-mail: lixl@cau.edu.cn

Tel.: +86-10-62731325

Fax: +86-10-62731016

P. Christie

Agricultural and Environmental Science Department,

Queen's University Belfast,

Newforge Lane,

Belfast BT9 5PX, UK

\section{Introduction}

Arbuscular mycorrhizal fungi (AMF) are ubiquitously associated with the large majority of plant families in different ecosystems across the world ranging from the tropics (Janos 1980; Zhao et al. 2001b) or arctic-alpine habitats (Haselwandter and Read 1980; Haselwandter 1987) to mesic (Rickerl et al. 1994; Ingham and Wilson 1999; Muthukumar and Udaiyan 2000) and arid habitats (Barrow et al. 1997; Stutz et al. 2000; O'Connor et al. 2002). China embraces a large diversity of climatic conditions and soil types, resulting in a wide range of ecosystems and vegetation structure. The examination of AMF began in China in the 1970s (Tang 1977). Early research focused entirely on the mycorrhizal status of plants, mostly on the degree of root colonization and spore counts in the field. The taxonomy of AMF was studied in the mid-1980s and several manuals for the identification of AMF were published in Chinese (Tang and Zang 1984; Zhang and Wang 1991a). This work led to an increase in the identification of AMF in surveys within China. The number of researchers investigating these fungi also increased. Over the past 10 years, studies have resulted in more than 100 papers on taxonomy and diversity, most of which were performed by observation of spores of AMF.

From north to south, the People's Republic of China covers the equatorial belt, the tropics, the subtropics, a moderate temperate zone and a cold temperate zone, and from east to west, the lands comprise forests, grasslands, deserts, plains, hills, and mountains. In terms of moisture, the country can be sectored from southeast to northwest into humid (32\% of land area), semihumid (15\%), semiarid $(22 \%)$, and arid zones $(31 \%)$. Climates are dominated by dry seasons and wet monsoons, and differ from region to region because of the country's extensive and complex topography. According to the climate and terrain, the mainland of China is traditionally divided into six geographical zones (Fig. 1). To the south of the Nanling Mountains, rains are prolific and temperatures are high all year round. The Yangtze and Huaihe river valleys in central south China have four distinctive seasons. In northeast 
China, summer is short but with much sunshine, while winter is long and cold. Precipitation is limited in northwest China. In southwest China at low latitudes, the land is highly elevated and has characteristically vertical seasonal zones.

Due to the influences of hydrothermal conditions and geomorphology, Chinese soil distribution shows zonality in latitude and longitude. In east China, for instance, the soils vary between south and north from latosols through lateritic red earths, red earths, yellow-brown earths, and brown earths to dark brown earths, while from the coast to the interior (east to west), soils also show regular variation with decreasing humidity. For example, in the Temperate Zone, the soils vary from dark brown earths, black soils, chernozems, castenoziems, brown pedocals, and gray to brown desert soils. Agricultural soils are mostly concentrated on the eastern plains, the Loess Plateau, the Sichuan Basin, and large areas of the southeastern part of the country where the greatest population densities and the longest history of cultivation are.

This review aims to summarize the information that is presently available on plant mycorrhizal status, AMF species richness and germplasm collections, and AMF community diversity in different habitats and vegetation types within China.

\section{Mycorrhizal status of plants}

Trappe (1987) indicates that while arbuscular mycorrhiza (AM) have been recorded in all angiosperm orders examined, information is available for only about $3 \%$ of known plant species. About 30,000 plant species (one eighth of the world total) are present in China, which is almost twice the number found in the United States and Canada combined. This number includes about 8,000 species of medicinal and economically important plants and about 7,500 species of trees and shrubs. Chinese researchers have extensively examined the mycorrhizal status of plant species in terrestrial ecosystems, studying nearly 800 plant species belonging to 150 families.

Early work in China focused mainly on the mycorrhizal status of cultivated plants. Some 120 agricultural plant species, including grain, oil, and economic crops and horticultural and Chinese medicinal plants, have been found to form associations with AMF (Table 1). In addition, wild plants inhabiting a range of environments, such as heathland, mountain areas, grasslands, woodlands, and tropical forests, were also surveyed (Gong et al. 1997; Gai et al. 2000a; Zhao 2000; Chen et al. 2001; Zhao et al. 2001b, 2003; Wang and Liu 2002; Muthukumar et al. 2003; Bao and Yan 2004; Ding et al. 2004). Mycorrhizal incidence among wild herbaceous plants is consistently high, with over $90 \%$ of the species examined (about 300) exhibiting AMF colonization, and AM associations also occur in trees and shrubs of certain climatic zones. Gong et al. (1997) concluded that members of 48 plant families,

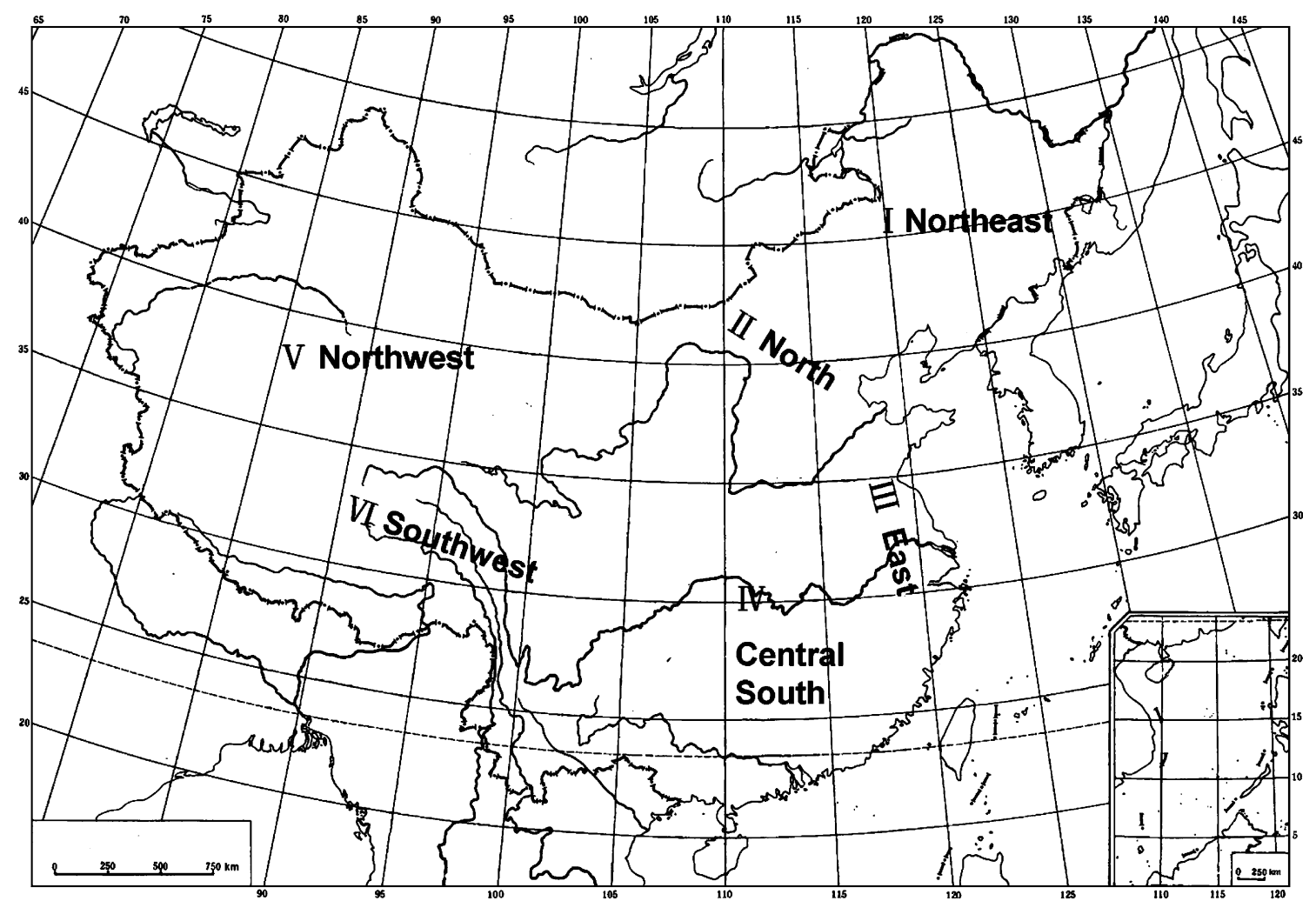

Fig. 1 Sketch map of China showing the six geographical zones 
out of a total of 78, form AM associations. Other surveys have focused on subtropical and tropical vegetation (Wu et al. 2001; Zhao et al. 2001a,b; Zhang et al. 2003a). The incidence of AM tends to be higher in subtropical and tropical tree species compared with those in temperate zones. A survey in the subtropical Yunnan province showed that about $80 \%$ of tree species form AM associations (Muthukumar et al. 2003). Even the Dipterocarpaceae, typically considered to be ectomycorrhizal (Smith and Read 1997), exhibit AMF colonization in China (Shi et al. 2003a,b). Pteridophytes are of ancient origin and some members are assumed to be AM (Gemma et al. 1992). In subtropical China, AMF structures have been observed in $31(91 \%)$ out of 34 pteridophyte species in Dujiangyan (Zhang et al. 2004a), which is very different from the results of Zhao (2000), who reported very low occurrence $(17 \%)$ of AMF amongst 256 pteridophyte species in a tropical region of Yunnan, southwest China.

Some plant families are still assumed to never or rarely form mycorrhizal associations (Newman and Reddell 1987; Tester et al. 1987), such as members of the Cyperaceae, Brassicaceae, Caryophyllaceae, Juncaceae, and Amaranthaceae (Smith and Read 1997). The AM status of Cyperaceae was found to vary in different habitats of China. Muthukumar et al. (2003) found no mycorrhizal structures in three sedge species in the Yunnan province. In contrast, most of 22 ecotypes examined in nine sedge species from Tibetan grasslands were mycorrhizal (Gai et al. 2005). Muthukumar et al. (2004) reviewed current information on mycorrhizal associations in sedges, and concluded that mycorrhiza formation is greatly influenced by environmental conditions. The mycorrhizal status of some Amaranthaceae species was also studied by Chen et al. (2001) in agricultural parts of the red soil area, by Bao and Yan (2004) in the grasslands of midwestern Inner Mongolia, and by Yang et al. (2002) in the Xishuangbanna Tropical Botanical Garden in south China. Three out of eight species were found to form AM. However, all members of the Brassicaceae, Caryophyllaceae, or Juncaceae examined to date in China are nonmycorrhizal (Gai et al. 2000a; Chen et al. 2001; Bao and Yan 2004). Distinctive morphotypes of AM have also been reported in different plant species. Bao and Yan (2004) studied mycorrhiza in 125 plant species in the central and western grasslands of Inner Mongolia; out of 104 plant species investigated, 83\% formed AM associations and most were of the Arum type $(65 \%)$.

\section{Spore communities in different habitats}

Discrimination between AMF species and the measurement of their richness, abundance, and distribution in natural habitats is central to understanding community structure and dynamics, ecological assembly rules, and biogeographical patterns. Much of the influential work has focused on comparative geographical studies and on patterns of nonrandom (deterministic) community assem-
Table 1 Cultivated plant species reported to be arbuscular mycorrhizal in China

Grain crops ${ }^{\text {a, b, c, d, e }}$

Avena nuda $\mathrm{L}$.

Oryza sativa L.

Eriogonum fasciculatum Benth.

Glycine max Merrill

Hordeum vulgare L.

Ipomoea batatas (L.) Lam.

Manihot esculenta Crant.

Oil crops ${ }^{\mathrm{a}, \mathrm{c}, \mathrm{d}, \mathrm{e}}$

Arachis hypogaea L.

Economic crops ${ }^{\mathrm{b}, \mathrm{c}, \mathrm{f}, \mathrm{g}, \mathrm{h}, \mathrm{i}}$

Agave sisalana Perrine

Boehmeria nivea (L.) Gaudich

Camellia sinensis (L.) O. Kuntze

Cannabis sativa L.

Coffea arabica $\mathrm{L}$.

Gossypium arboreum L.

Horticultural plants

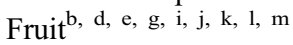

Actinidia chinensis Planch.

Ananas comosus (L.) Merr.

Averrhoa carambola $\mathrm{L}$.

Canarium album Raeusch

Carica papaya $\mathrm{L}$.

Carya cathayensis Sargent

Castanea mollissima Blume

Citrus aurantium L.

Citrus grandis Osbeck.

Citrus limon Burmann

Citrus sinensis Osbeck

Citrus sunki Hot.

Cocos nucifera L.

Corylus heterophylla Fisher

Crataegus pinnatifolia Bunge

Dimocarpus longana Lour.

Makino

Eriobotrya japonica Lindley

Ficus carica L.

Fortunella margarita (Lour.)

Swingle

Vegetables $^{\mathrm{b}, \mathrm{c}, \mathrm{d}, \mathrm{e}, \mathrm{n}}$

Allium cepa L.

Allium fistulosum L.

Allium porrum L.

Allium sativum $\mathrm{L}$.

Allium tuberosum Rottl.

Amaranthus mangostanus L.

Apium graveolens L.

Asparagus officinalis L.

Capsicum annuum L.

Citrullus lanatus (Thunb.)

Matsum \& Nakai

Cucumis sativus L.

Daucus carota L.
Setaria italica (L.) Beauv.

Sorghum vulgare Pers.

Triticum aestivum $\mathrm{L}$.

Vigna rabiata (L.)Wilczek

Zea mays L.

Sesamum indicum L.

Helianthus annuus L.

Hevea brasiliensis Müll. Arg.

Morus alba L.

Nicotiana tabacum L.

Piper nigrum L.

Saccharum sinense L.

Fragaria $\times$ ananassa Duch.

Gingko biloba L.

Juglans regia L.

Litchi chinensis Sonn.

Malus pumila Mill.

Mangifera indica L.

Manilkara zapota (L.)

Van Royen

Morus alba L.

Musa sapientum L.

Myrica rubra Sieb. et Zucc.

Pistacia vera $\mathrm{L}$.

Prunus armeniaca L.

Prunus cerasus L.

Prunus persica L.

Prunus salicina Lindl.

Psidium guajava $\mathrm{L}$.

a Punica granatum L.

Pyrus bretschneideri Rehd.

Vitis vinifera $\mathrm{L}$.

Zizyphus jujuba Mill.

Lactuca sativa L.

Luffa cylindrica (L.) Roem.

Lycopersicon esculentum Mill.

Momordica charantia L.

Phaseolus vulgaris L.

Pisum sativum L.

Solanum melongena L.

Solanum tuberosum L.

Spinacia oleracea L.

Toona sinensis (Juss.) Roem.

Vigna sesquipedalis Koern

Vigna unguiculata (L.) Walp. 
Table 1 (continued)

\begin{tabular}{|c|c|}
\hline Dioscorea batatas Decne. & $\begin{array}{l}\text { Zanthoxylum schinifolium } \\
\text { Zucc. }\end{array}$ \\
\hline Ipomoea aquatica Forsk. & Zingiber officinale Roscoe \\
\hline Lablab purpureus (L.) Sweet & Zizania caduciflora Hand. \\
\hline \multicolumn{2}{|l|}{ Flowers $\mathrm{b}, \mathrm{e}, \mathrm{n}, \mathrm{o}, \mathrm{p}$} \\
\hline Aloe vera $\mathrm{L}$ & Rosa chinensis Jacq. \\
\hline $\begin{array}{l}\text { Leucaena leucocephala (Lam.) } \\
\text { de Wit }\end{array}$ & Rosa x hybrida Hort. \\
\hline $\begin{array}{l}\text { Gynostemma pentaphylla } \\
\text { (Thunb.) Makino }\end{array}$ & Mimosa pudica L. \\
\hline Jasminum sambac (L.) Ait. & Petunia hybrida Vilm. \\
\hline Gladiolus gandavensis & Saintpaulia ionantha \\
\hline Van Houtte & H. Wendl. \\
\hline Lonicera japonica Thunb. & Lilium longiflorum Thumb. \\
\hline Paeonia suffruticosa Andrews & $\begin{array}{l}\text { Myosotis sylvatica Ehrh. } \\
\text { ex Hoffm. }\end{array}$ \\
\hline \multicolumn{2}{|l|}{ Medicinal plants ${ }^{\mathrm{b}, \mathrm{e}, \mathrm{q}, \mathrm{r}, \mathrm{s}, \mathrm{t}}$} \\
\hline Datura stramonium L & Panax quiquefolium L. \\
\hline Lycium chinensis Mill. & Gentiana scabra Bge. \\
\hline $\begin{array}{l}\text { Mentha haplocalyx Briq. } \\
\text { Panax ginseng CA Mey. }\end{array}$ & Schizonepeta tenuifolia Briq. \\
\hline
\end{tabular}

${ }^{\mathrm{a}}$ Gai et al. (2004)

${ }^{b} \mathrm{Niu}$ (1994)

${ }^{c}$ Peng et al. (1990)

${ }^{\mathrm{d}}$ Zhang and Wang (1991b)

${ }^{\mathrm{e}}$ Zhang et al. (1992)

${ }^{f}$ Fang et al. (1986)

${ }^{\mathrm{g}}$ Liu et al. (1987)

${ }^{\mathrm{h}}$ Wang and $\mathrm{Hu}$ (1989)

${ }^{\mathrm{i}}$ Wang et al. (1996)

${ }^{\mathrm{j}}$ Tang and Zang (1984)

${ }^{\mathrm{k}} \mathrm{Wu}$ et al. (1994)

${ }^{1}$ Zhang et al. (1996)

m Zhou et al. (1992)

${ }^{\mathrm{n}} \mathrm{Lin}$ and Hao (1989)

${ }^{\circ} \mathrm{Li}$ and Wang (1999)

${ }^{\mathrm{p}} \mathrm{Yi}$ and Ding (1990)

${ }^{\mathrm{q}}$ Wang et al. (1998a)

${ }^{\mathrm{r}}$ Wei and Wang (1989)

${ }^{\mathrm{s}}$ Wei and Wang (1991)

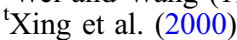

bly by a small number of fungal species that could be identified.

Species richness and community diversity across China

A prerequisite to any study of population structure and diversity is the clarification of the species concept for AMF (Dodd et al. 1996). Based on the lack of sexual reproduction in AMF, it has been suggested that applying the species concept could be difficult and that it would be more appropriate to base the description of biodiversity on genetic diversity (Sanders et al. 1996). However, even for interpretation of the most recent molecular ecological studies, genetic variation within one population and among different isolates of one species can be quite high (Antoniolli et al. 2000; Clapp et al. 2001; Redecker et al. 2003). Morphospecies are units of classical taxonomy and units of experimental manipulation when linking organismal and molecular scales.

About 200 AMF species have so far been discovered worldwide. Despite this low taxonomic diversity for such a widespread group of organisms (Allen et al. 2003), each species may contain considerable genetic diversity. Analysis of local populations adapted to various conditions is therefore essential. A total of 104 AMF species within nine genera have been reported in the rhizosphere of different plant species in various habitats in China since the 1980s and 12 new species were discovered in these surveys (Table 2). Occurrence of AMF genera varies in abundance and frequency across China. Glomus species are widely distributed in various habitats and dominate communities in the cold or temperate parts of the north and west, as well as in the tropical and subtropical vegetation in the south and east, of the country. The frequency of occurrence and abundance of sporulation by Glomus species are much higher than in other genera. Acaulospora is the second most dominant genus in China, ranking after Glomus in the north and west and similar to Glomus in the south and east. Gigaspora and Scutellospora species are found mostly in the coastal sand dunes and islands, and have been reported from southern and eastern areas that are near the sea (Wang et al. 2004a). These genera also dominate in the Shandong Peninsula, especially in association with wild plants and in woodlands (Gai et al. 2000a; Wang et al. 2003, 2004a,b). Other genera seem to be less common in China, with only a few examples of species, such as Paraglomus occultum and Entrophospora infrequens, reported (Zhang et al. 1998b; Gai et al. 2000a).

Frequency of occurrence also varies at the species level. Glomus mosseae has been found at almost all sites investigated (90\%), associating with a variety of crop and wild plant species in both natural and disturbed soils. Glomus mosseae is a dominant species in habitats of northern China, but is found at lower frequencies in habitats of southern China (Table 3). Acaulospora species dominate in the latter habitats. The frequency of $G$. mosseae was found to decrease from north to south along the southern and eastern coasts (Zhang et al. 1999). Species richness showed an increasing trend from north to south (Table 3).

Species diversity in natural and disturbed habitats has been compared in several studies (Wang et al. 2003; Zhang et al. 2004b). Results vary with ecological features and histories of the habitats investigated. Wang et al. (2003) compared richness, distribution, and sporulation abundance of AMF species in island forests, saline soils, coal mine spoil heaps, and degraded grasslands. Species richness in natural island forests was much greater than in any of the three disturbed habitats. Glomus species were dominant at all sampling sites, but the frequency and relative sporulation by Acaulospora species were higher at coal mine spoil sites. Gigaspora species sporulated more abundantly than Acaulospora species in island forest areas. Zhang et al. (2004b) compared the diversity of AMF 
Table 2 AMF reported from different geographical areas of China

\begin{tabular}{|c|c|c|}
\hline AMF & Reference & Habitat and vegetation type \\
\hline \multicolumn{3}{|l|}{ Acaulospora } \\
\hline Acaulospora bireticulata Rothwell \& Trappe & Peng et al. 1990 & $\mathrm{CS}, \mathrm{N}, \mathrm{NE} /$ farmland \\
\hline Acaulospora cavernata Blaszkowski & Xing et al. 2000 & NE/ Panax field \\
\hline Acaulospora denticulata Sieverding \& Toro & Wu et al. $1995 \mathrm{a}$ & $\mathrm{E} /$ tea garden with red soil \\
\hline Acaulospora dilatata Morton & Zhang et al. $1998 \mathrm{a}$ & $\mathrm{CS}, \mathrm{E} /$ tea garden and cocoa orchard \\
\hline Acaulospora elegans Trappe \& Gerdemann & Peng et al. 1990 & SW, CS/ farmland \\
\hline Acaulospora excavata Ingleby \& Gerdemann & Zhang et al. 2001 & $\mathrm{CS} /$ aluminum mine site \\
\hline Acaulospora foveata Trappe \& Janos & Wu and Chen 1986 & Taiwan / bamboo vegetation \\
\hline Acaulospora lacunosa Morton & Gai and Liu 2000 & E/ wild plants in heathland and upland \\
\hline Acaulospora laevis Gerdemann \& Trappe & Wu and Chen 1986 & Taiwan-E/ bamboo vegetation \\
\hline Acaulospora nicolsonni Walker, Read and Sanders & Fang et al. 2000 & $\mathrm{CS} /$ tobacco field \\
\hline Acaulospora longula Spain \& Schenck & Zhang et al. 1992 & $\mathrm{NW}$ / wild chrysanthemum at lakeside \\
\hline Acaulospora mellea Spain \& Schenck & Hu 1988 & Taiwan/ fir and Taiwania fir \\
\hline Acaulospora morrowae Spain \& Schenck & Hu 1988 & Taiwan / fir and Taiwania fir \\
\hline Acaulospora myriocarpa Spain, Sieverding \& Schenck & Hu 1988 & Taiwan / fir and Taiwania fir \\
\hline Acaulospora polonica Blaszkowski & Zhang et al. 2001 & $\mathrm{CS} /$ aluminum mine site \\
\hline Acaulospora rehmii Sieverding \& Toro & Shi et al. $2003 b$ & CS/ Dipterocarpaceae at Jianfengling mountain \\
\hline Acaulospora rugosa Morton & Zhang et al. 1998a & E/ longan orchard \\
\hline Acaulospora scrobiculata Trappe & Wu and Chen 1986 & Taiwan / bamboo vegetation \\
\hline Acaulospora spinosa Walker \& Trappe & Hu 1988 & Taiwan-S/ fir and Taiwania fir \\
\hline Acaulospora taiwania $\mathrm{Hu}^{\mathrm{a}}$ & Hu 1988 & Taiwan-S/ fir and Taiwania fir \\
\hline Acaulospora tuberculata Tanos \& Trappe & Zhao and Du 1997 & $\mathrm{SW} /$ tropical pteridophytes \\
\hline Acaulospora undulata Sieverding & Zhang et al. 2001 & $\mathrm{CS} /$ aluminum mine site \\
\hline \multicolumn{3}{|l|}{ Archeospora } \\
\hline Archeospora leptoticha (Schenck \& Smith) Morton \& Redecker & Hu 1988 & Taiwan-S/ fir and Taiwania fir \\
\hline Archeospora trappei (Ames \& Linderman) Morton \& Redecker & Wu and Chen 1986 & Taiwan-S/ bamboo vegetation \\
\hline \multicolumn{3}{|l|}{ Diversispora } \\
\hline Diversispora spurca Pfeiffer, Walker \& Bloss & Gai et al. 2004 & $\mathrm{~N} /$ farmland \\
\hline \multicolumn{3}{|l|}{ Entrophospora } \\
\hline Entrophospora infrequens (Hall) Ames \& Schneider & Peng et al. 1990 & $\mathrm{CS} /$ farmland \\
\hline Entrophospora colombiana Spain \& Schenck & Zhang et al. $2003 \mathrm{~b}$ & $\mathrm{SW} /$ subtropical fir \\
\hline Entrophospora kentinensis $\mathrm{Wu} \& \mathrm{Liu}^{\mathrm{a}}$ & Wu et al. $1995 b$ & Taiwan / bamboo in highlands \\
\hline \multicolumn{3}{|l|}{ Gigaspora } \\
\hline Gigaspora albida Walker \& Rhodes & Fang et al. 2000 & E/ tobacco field \\
\hline Gigaspora alboaurantiaca ${ }^{\mathrm{a}}$ & Chou et al. 1991 & Taiwan / \\
\hline Gigaspora decipiens Hall \& Abbott & Liu et al. 2002 & $\mathrm{E} /$ island forest \\
\hline Gigaspora gigantea (Nicol.\& Gerd.) Gerdemann \& Trappe & Wu and Chen 1986 & Taiwan / bamboo vegetation \\
\hline Gigaspora margarita Becker \& Hall & Peng et al. 1990 & $\mathrm{CS}, \mathrm{N} /$ farmland \\
\hline \multicolumn{3}{|l|}{ Glomus } \\
\hline Glomus aggregatum Schenck \& Smith & Hu 1988 & Taiwan / fir and Taiwania fir \\
\hline Glomus albidum Walker \& Rhodes & Wang and $\mathrm{Hu} 1989$ & $\mathrm{SC} /$ cotton field \\
\hline Glomus ambisporum Smith \& Schenck & Wang and $\mathrm{Hu} 1989$ & $\mathrm{SC} /$ cotton field \\
\hline Glomus australe (Berk.) Berch & Zhang et al. 2003b & SW/ subtropical pteridophytes \\
\hline Glomus caledonium Nicolson \& Gerdemann & Wu and Chen 1986 & Taiwan / bamboo vegetation \\
\hline Glomus canadense Trappe \& Gerdemann & Shi et al. 2004 & CS/ Dipterocarpaceae at Diaoluo mountain \\
\hline Glomus citricolum Tang \& Zang ${ }^{\mathrm{a}}$ & Tang and Zang 1984 & $\mathrm{CS} /$ citrus orchard \\
\hline Glomus claroideum Schenk \& Smith & Peng et al. 1990 & $\mathrm{SW}, \mathrm{CS}, \mathrm{N}, \mathrm{NE} /$ farmland \\
\hline Glomus clarum Nicolson \& Schenk & Hu 1988 & Taiwan/ fir and Taiwania fir \\
\hline Glomus clavisporum (Trappe) Almeida \& Schenck & Wu and Chen 1986 & Taiwan/ bamboo vegetation \\
\hline Glomus constrictum Trappe & Fang et al. 1986 & E/ tobacco field \\
\hline Glomus convolutum Gerdemann \& Trappe & Zhang et al. $2003 \mathrm{~b}$ & SW/ subtropical pteridophytes \\
\hline Glomus coremioides (Berk \& Broome) Redecker et Morton & Wu and Chen 1986 & Taiwan/ bamboo vegetation \\
\hline Glomus cunninghamia $\mathrm{Hu}^{\mathrm{a}}$ & Hu 1988 & Taiwan/ fir and Taiwania fir \\
\hline Glomus delhiense Mukerji, Bhattacharjee \& Tewari & Liu et al. 2001 & E/ tabacco field \\
\hline
\end{tabular}


Table 2 (continued)

\begin{tabular}{|c|c|c|}
\hline AMF & Reference & Habitat and vegetation type \\
\hline Glomus dimorphicum Boyetchko \& Tewari & Wang et al. 1998a,b & $\mathrm{CS} /$ Casuarina on beach \\
\hline Glomus etunicatum Becker \& Gerdemann & Wu and Chen 1986 & Taiwan/ bamboo vegetation \\
\hline Glomus fasciculatum (Thaxter) Gerdemann \& Trappe & Wu and Chen 1986 & Taiwan/ bamboo vegetation \\
\hline Glomus fulvum (Berk \& Broome) Trappe \& Gerdemann & Wu et al. 2001 & NW/ Taiba Mountain Nature Reserve \\
\hline Glomus geosporum (Nicol. \& Gerd.) Walker & Wang and $\mathrm{Hu} 1989$ & $\mathrm{CS} /$ cotton field \\
\hline Glomus gibbosum Blaszkowski & Zhang et al. 2003b & $\mathrm{SW} /$ subtropical pteridophytes \\
\hline Glomus globiferum Koske \& Walker & Zhang et al. $2003 \mathrm{~b}$ & $\mathrm{SW} /$ subtropical pteridophytes \\
\hline Glomus glomerulatum Sieverding & Liu et al. 2001 & E/ tobacco field \\
\hline Glomus lacteum Rose \& Trappe & Fang et al. 2000 & WS/ tobacco field \\
\hline Glomus liquidambaris (Wu \& Chen) Almeida \& Schenck ${ }^{\mathrm{a}}$ & Wu and Chen 1987 & Taiwan / bamboo vegetation \\
\hline Glomus macrocarpum Tul. \& Tul. & Hu 1988 & Taiwan / fir and Taiwania fir \\
\hline Glomus magnicaule Hall & Shi et al. $2003 b$ & CS/ Dipterocarpaceae at Jianfengling mountain \\
\hline Glomus manihotis Howeler, Sieverding \& Schenck & Wu et al. 1994 & $\begin{array}{l}\text { E/ woodland, farmland and citrus orchard on red } \\
\text { soil }\end{array}$ \\
\hline Glomus melanosporum Gerdemann \& Trappe & Wang and Liu 2002 & E/ saline-alkaline soil of Yellow River Delta \\
\hline Glomus microaggregatum Koske, Gemma \& Olexia & Zhang et al. 1996 & E/ farmland and heathland \\
\hline Glomus monosporum Gerdemann \& Trappe & Zhao 2000 & SW/ tropical or subtropical pteridophytes \\
\hline Glomus mosseae (Nicol. \& Gerd.) Gerdemann \& Trappe & Fang et al. 1986 & E/ tobacco field \\
\hline Glomus sinuosum (Gerd. \& Bakshi) Almeida \& Schenck & Wang et al. 1992 & $\mathrm{CS} /$ Acacia confusa nursery \\
\hline Glomus spinosum $\mathrm{Hu}^{\mathrm{a}}$ & $\mathrm{Hu} 2002$ & Taiwan/ fir \\
\hline Glomus taiwanense (Wu \& Chen) Almeida \& Schenck $^{\mathrm{a}}$ & Wu and Chen 1987 & Taiwan/ bamboo vegetation \\
\hline Glomus tenebrosum (Thaxter) Berch & Wang and Liu 2002 & E/ saline-alkaline soil of Yellow River Delta \\
\hline Glomus tortuosum Schenck \& Smith & Wu et al. 2000 & NW/ fir at Taiba Mountain \\
\hline Glomus verruculosum Blaszkowski \& Tadych & Li et al. 2004 & SW/ dry-hot valley of Jinsha River \\
\hline Glomus versiforme (Karsten) Berch & $\begin{array}{l}\text { Zhang and Wang } \\
\text { 1991b }\end{array}$ & $\mathrm{N}, \mathrm{NE} /$ farmland and heathland \\
\hline Glomus viscosum Nicolson & Li et al. 2004 & SW/ dry-hot valley of Jinsha River \\
\hline \multicolumn{3}{|l|}{ Pacispora } \\
\hline Pacispora scintillans (Rose and Trappe) Oehl \& Sieverd. & Hu 1988 & Taiwan / fir and Taiwania fir \\
\hline Pacispora chimonobambusae (Wu and Liu) Oehl \& Sieverd ${ }^{\mathrm{a}}$ & Wu et al. $1995 b$ & Taiwan / bamboo in highlands \\
\hline \multicolumn{3}{|l|}{ Paraglomus } \\
\hline Paraglomus occultum (Walker) Morton \& Redecker & Peng et al. 1990 & $\mathrm{CS}, \mathrm{N}, \mathrm{NE} /$ farmland \\
\hline \multicolumn{3}{|l|}{ Scutellospora } \\
\hline Scutellospora aurigloba (Hall) Walker \& Sanders & Peng et al. 1990 & $\mathrm{CS} /$ farmland \\
\hline Scutellospora calospora Walker \& Sanders & Hu 1988 & Taiwan/ fir and Taiwania fir \\
\hline Scutellospora coralloidea Walker \& Sanders & Pan et al. $1997 b$ & NW/ wild plants in the Loess Plateau \\
\hline Scutellospora erythropa (Nicol.\& Gerd.) walker \& Sanders & Pan et al. $1997 \mathrm{~b}$ & NW/ wild plant in the Loess Plateau \\
\hline Scutellospora fulgida Koske \& Walker & Wang et al. 1998a,b & $\mathrm{SW} /$ casuarina at seaside \\
\hline
\end{tabular}


Table 2 (continued)

\begin{tabular}{lll}
\hline AMF & Reference & Habitat and vegetation type \\
\hline Scutellospora gilmorei (Trappe \& Gerd.) Walker \& Sanders & Hu 1988 & Taiwan/ fir and Taiwania fir \\
Scutellospora gregaria (Schenck \& Nicol.) Walker \& Sanders & Zhao 1998 & SW/ tropical, subtropical pteridophytes \\
Scutellospora heterogama (Nicol.\& Gerd.) Walker \& Sanders & Wu et al. 1994 & E/ Citrus orchard, woodland with red soil \\
Scutellospora nigra (Readhead) Walker \& Sanders & Hu 1988 & Taiwan/ fir and Taiwania fir \\
Scutellospora pellucida (Nicol.\& Schenck) Walker \& Sanders & Hu 1988 & Taiwan/ fir and Taiwania fir \\
Scutellospora persica (Koske \& Walker) Walker \& Sanders & Zhao 1998 & SW/ tropical, subtropical pteridophytes \\
Scutellospora reticulata (Koske, Miller \& Walker) Walker \& & Wang et al. 1998a,b & E/ pot herb \\
Sanders & & \\
Scutellospora trirubiginopa Pan \& Zang & Pan et al. 1997a & NW/ wild plants on Loess Plateau \\
Scutellospora verrucosa (Koske \& Walker) Walker \& Sanders & Yang et al. 2004 & SW/ Dodonaea viacosa \\
\hline
\end{tabular}

$S W$ southwest China, $C S$ central south China, $N$ north China, $E$ east China, $N W$ northwest China, $N E$ northeast China

${ }^{a}$ New species described in China

in deforested (Mantoushan) and natural forest (Banruosi) areas in the subtropical region of Dujiangyan, southwest China. They found that Acaulospora and Glomus were the dominant genera in both regions. The Shannon-Weiner index of AM fungal diversity was higher in the natural forest (2.67) than in the deforested area (2.15). The annual herbaceous plants were assumed to play a major role in maintaining and increasing sporulation and species richness in the deforested area.

Comparisons between different geographical regions

Habitat type is an important factor influencing AMF communities (Stutz et al. 2000). Not surprisingly, AMF have been found in soils of all six geographical zones of China (Table 3). Differences among the ecological zones in the diversity of genera and species are considerable. Unfortunately, there has been no study looking at one plant species across all the zones, and so, comparisons are virtually impossible because different vegetation types were selected in surveys, and soil and climatic conditions in some studies were not clear. However, the overall plant diversity of southeastern areas is much higher than that in the northwest, and it is tempting to suggest that a combination of climatic and plant influences may contribute to the greater diversity of AMF in southern and eastern areas compared with those of the north and west.

\section{Influence of plant taxa}

Numerous studies in China have focused on AM fungal communities and their interaction with plant species, especially the types and intensity of mycorrhizal associations in different vegetation types (Peng et al. 1990; Zhang et al. 2004a; Shi et al. 2003b). Because agriculture plays a central role in most rural parts of China, many research groups have focused on field crops or on wild plants in cultivated areas. Gai et al. (2000a, 2004) surveyed the fungal diversity of field crops and wild plants in northern China and found that many more AMF species were associated with wild plants than with field crops. The abundance of sporulation showed the opposite trend. The dominant AMF species also changed. Species in Gigaspora and Scutellospora were much more frequently associated with wild plants than with field crops. Jansa et al. (2002) observed a similar pattern when comparing the diversity and structure of AMF communities as affected by tillage in a temperate soil. The species composition of AMF in the rhizosphere of pteridophytes, which are thought to have been the earliest examples of AM plants in evolution (Gemma et al. 1992), was investigated in some subtropical and tropical areas in China (Zhao 1998; Zhang et al. 2004a). The dominant fungal genera associated with these plant taxa were Acaulospora and Glomus at both Dujiangyan in central south China and Xishuangbanna in southwest China. However, AMF species richness and spore abundance differed with the pteridophyte species.

\section{Effect of soil conditions}

Soil properties appear to influence the distribution of AMF genera and species, at least based on sporulation patterns (Johnson et al. 1992; Bever et al. 2002). It has been shown in numerous studies that $\mathrm{pH}$ is an important factor influencing AM fungal species composition in soils (see, for example, Wang 1985, 1993). Soils are mostly acid in the south of China ( $\mathrm{pH} 5-6$ ), whereas they are calcareous in the north ( $\mathrm{pH} 7-8$ ). Glomus appears to dominate in alkaline and neutral soils, while Acaulospora sporulates more abundantly in acid soils (Zhang et al. 1998b; Gai and Liu 2003), a pattern that parallels the regional distribution patterns of these genera. Soil type and organic matter content are also likely to influence AMF community composition. In China, AMF communities have been reported to vary between different soil types with, for example, Acaulospora species being more frequent in latosols, lateritic red earths, or paddy soils, and Gigaspora and Scutellospora species being more common in brown soils or paddy soils (Gai and Liu 2003; Zhang et al. 1999). Indications for the probable influence of soil organic matter on the distribution of some AMF species in China come 


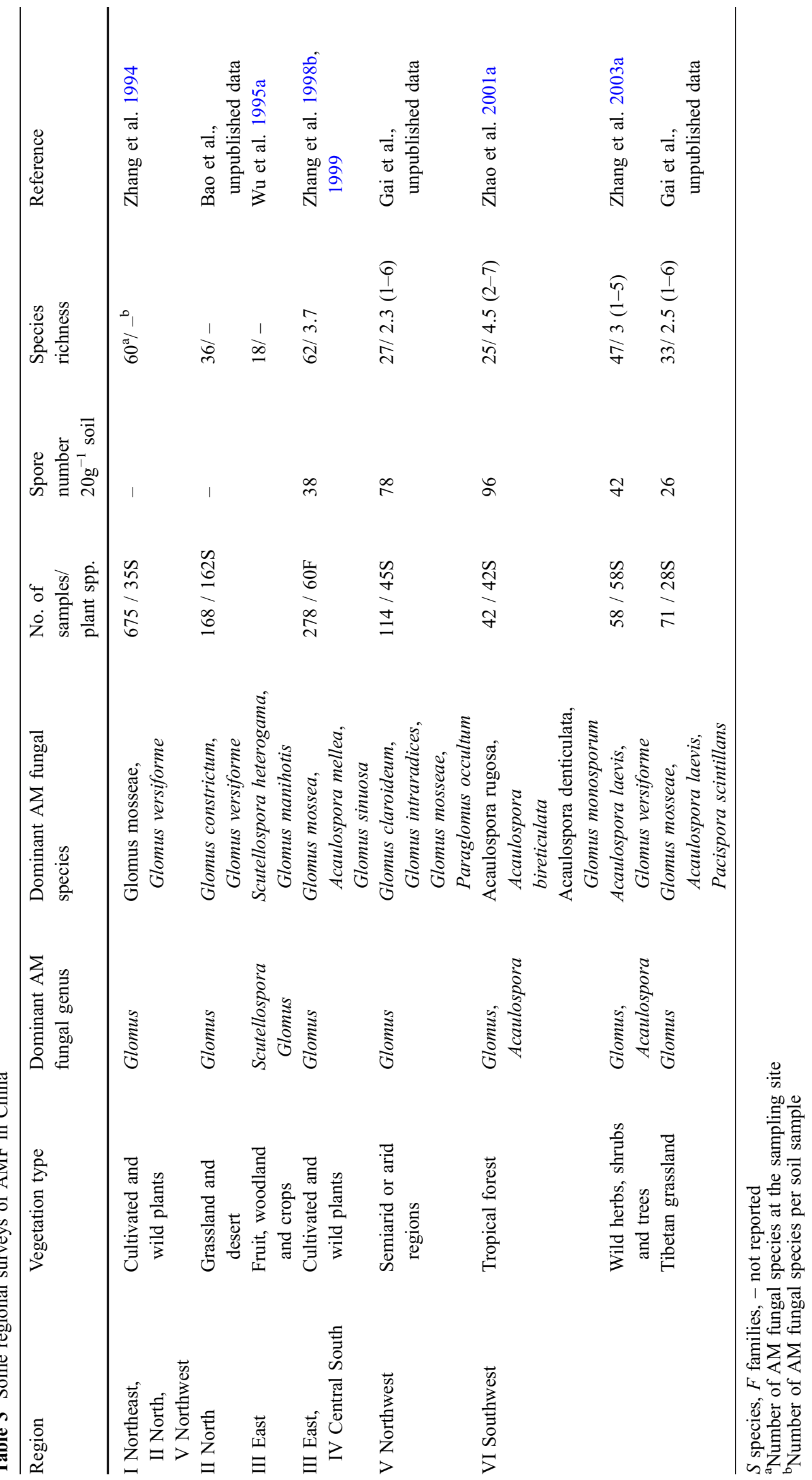


from the observations that, for example, the frequency of occurrence of $G$. mosseae decreased with increasing organic matter content, while Glomus sinuosum and Glomus taiwanense were found only when soil organic matter content was less than $1.5 \%$ (Zhang et al. 1999).

Specialist species in some habitats

AM fungal community structure shows some correspondence with habitat type. For example, some of the most commonly detected species in arid and semiarid zones of north China, such as G. mosseae, Glomus intraradices, and Glomus etunicatum (Zhang et al. 1994; Gai et al., unpublished data), are often also frequent in other arid or semiarid regions in the world (Bloss and Walker 1987; Stutz et al. 2000; Ferrol et al. 2004). The proliferation of small-spore species in the arid or semiarid regions of northwest and northeast China (Gai et al. unpublished data; $\mathrm{Li}$ and Zhao, 2005) approximates to similar findings in southwestern North America and Namibia (Stutz et al. 2000). Some AMF species are associated with unique habitats. For example, Pacispora scintillans was readily found in regions of high altitude such as Tibet and Xinjiang (Qiao et al. 2005; Gai et al., unpublished data) and was a dominant species in the grasslands of northern Tibet. Glomus formosanum was found to occur mainly in subtropical or tropical habitats, with no records from northern China so far (Wu and Chen 1987; Zhang et al. 1998b, 2004a). The phenomenon that some AMF species may prefer particular environments may be ascribed to local ecological factors and to regional ecological history. It has been proposed that environmental conditions may select a suite of AMF species that are available for colonization (Klironomos et al. 2001; Stutz et al. 2000), resulting in genetic diversity being limited to a particular species or genera in habitats with similar environmental conditions.

\section{AMF germplasm collections}

Efforts to develop germplasm collections of AMF in China have intensified in recent years. The Chinese Bank of Glomeromycota at the Beijing Academy of Agricultural and Forestry Science is the largest germplasm bank on the mainland, in which 56 isolates corresponding to 11 species from China are stored. Some of Chinese isolates have been registered in international banks: 50 are registered in the International Bank for the Glomeromycota (IBG) (http:// www.kent.ac.uk/bio/beg/), and five in the International Culture Collection of Arbuscular and Vesicular-Arbuscular Mycorrhizal Fungi (http://www.invam.caf.wvu.edu/). A Chinese Arbuscular Mycorrhizal Fungal database link with the IBG has also been set up (http://www.acad.polyu.edu. $\mathrm{hk} / \sim \mathrm{bccamf} /$ ) within the framework of a European project (http://www.dijon.inra.fr/mychintec/). In addition, collections of AMF germplasm continue to be maintained by various mycorrhizal research groups, for example, at the National Dong Hwa University in Taiwan, China Agricultural University in Beijing, and Huazhong Agricultural University in Wuhan.

\section{Future challenges}

Much research has been devoted to identifying mycorrhizal associations in diverse plant communities, characterizing fungal communities, and understanding the distribution patterns of AMF in different habitats in China. However, the mycorrhizal status and pattern of fungal diversity in some plant taxa and habitats remain poorly understood. Large-scale surveys across different ecological zones, including studies of AMF associated with single plant species, should be conducted with standard methods to allow broad comparisons and to address questions about biogeography on a continental scale. Chinese researchers envisage such pioneering studies in the near future.

The taxonomy of the Glomeromycota is presently in considerable flux, with conflicting morphological and molecular data sets, and the phylum for AMF has recently been revised several times (Morton and Redecker 2001; Schüßler et al. 2001; Walker and Schüßler 2004). Phylogenetic analysis for classification must be resolved using additional criteria that extend beyond morphology and ribosomal encoding genes. It is therefore important and urgent for Chinese scientists to also utilize and expand on new molecular tools to explore both classification and distribution of AMF species within roots and in soils.

Acknowledgements We thank anonymous reviewers and Vivienne Gianinazzi-Pearson for advice and encouragement during the preparation of this review. We are also grateful to the National Natural Science Foundation of China (Project 30370818), the Royal Society (China Exchange Project 15360) and the European Union (INCO-DEV Project ICA4-CT-2000-30014) for generous financial support.

\section{References}

Allen MF, Swenson W, Querejeta JI, Egerton-Warburton LM, Treseder KK (2003) Ecology of mycorrhizae: a conceptual framework for complex interactions among plants and fungi. Annu Rev Phytopath 41:271-303

Antoniolli ZI, Schachtman DP, Ophel-Keller K, Smith SE (2000) Variation in rDNA its sequences in Glomus mosseae and Gigaspora margarita spores from a permanent pasture. Mycol Res 104:708-715

Bao YY, Yan W (2004) Arbuscular mycorrhizae and their structural types on common plants in grasslands of midwestern Inner Mongolia. Biodivers Sci 12:501-508

Barrow JR, Havstad KM, McCaslin BD (1997) Fungal root endophytes in fourwing saltbush, Atriplex canescens, on arid rangelands of southwestern USA. Arid Soil Res Rehabil 11:177-185

Bever JD, Schultz PA, Pringle A, Morton JB (2002) Arbuscular mycorrhizal fungi: more diverse than meets the eye, and the ecological tale of why. Bioscience 51:923-931 
Bloss HE, Walker C (1987) Some endogonaceous mycorrhizal fungi of the Santa Catalina mountains in Arizona. Mycologia 79: 649-654

Chen X, Fang ZG, Tang JJ (2001) Investigation on host plants of vesicular arbuscular mycorrhizal fungi (VAMF) within weed communities in agricultural slope land in the red soil area of southeastern China. Biodivers Sci 9:122-128

Chou WN, Yen CH, Chung HH (1991) Species of Gigaspora and Scutellospora (Endogonaceae) in Taiwan. Trans Mycol Soc Rep China 6:3

Clapp JP, Rodriguez RA, Dodd JC (2001) Inter- and intra-isolate rRNA large subunit variation in Glomus coronatum spores. New Phytol 149:539-554

Ding Q, Jia GX, Jiang HB (2004) A survey of arbuscular mycorrhiza of wild flowers in Longtou Mountain area and its application. J Beijing For Univ 26:51-54

Dodd JC, Rosendahl S, Giovannetti M, Broome A, Lanfranco L, Walker C (1996) Inter- and intraspecific variation within the morphologically similar arbuscular mycorrhizal fungi Glomus mosseae and Glomus coronatum. New Phytol 133:113-122

Fang YC, Liu YR, Fang R (1986) The isolation and identification of endomycorrhizal fungi on tobacco. Acta Mycol Sinica 5: $185-190$

Fang YC, Huang Z, Liu YR (2000) Study on VA mycorrhizal flora of tobacco (Nicotiana tobacum). Acta Tob Sinica 6:26-31

Ferrol N, Calvente R, Cano C, Barea JM, Azcón-Aguilar C (2004) Analysing arbuscular mycorrhizal fungal diversity in shrubassociated resource islands from a desertification threatened semiarid Mediterranean ecosystem. Appl Soil Ecol 25:123-133

Gai JP, Liu RJ (2000) Arbuscular mycorrhizal fungi on wild plants. Mycosystema 19:24-28

Gai JP, Liu RJ (2003) Effect of soil factors on AMF in the rhizosphere of wild plants. Chin J Appl Ecol 14:470-472

Gai JP, Liu RJ, Li XL (2000a) Ecological distribution of arbuscular mycorrhizal fungi on wild plants in different vegetation regions of Shandong Province. Chin J Ecol 19:18-22

Gai JP, Liu RJ, Meng XX (2000b) Arbuscular mycorrhizal fungi on wild plants. Mycosystema 19:205-211

Gai JP, Feng G, Li XL (2004) Diversity of arbuscular mycorrhizal fungi in field soils from North China. Biodivers Sci 12: $435-440$

Gai JP, Cai XB, Feng G, Christie P, Li XL (2005) Arbuscular mycorrhizal fungi associated with sedges on the Tibetan plateau. Mycorrhiza DOI: 10.1007/s00572-005-0031-8

Gemma JN, Koske RE, Flynn T (1992) Mycorrhizae in Hawaiian pteridophytes: occurrence and evolutionary significance. Am J Bot 79:843-852

Gong MQ, Chen YL, Zhong CL (1997) Mycorrhizal research and application. China Forestry Publishing House, Beijing, p 223

Haselwandter K (1987) Mycorrhizal infection and its possible ecological significance in climatically and nutritionally stressed alpine plant communities. Angew Bot 61:107-114

Haselwandter K, Read DJ (1980) Fungal associations of roots of dominant and sub-dominant plants in high-alpine vegetation systems with special reference to mycorrhiza. Oecologia 45: $57-62$

Hu HT (1988) Study on the endomycorrhizae of Chinese fir (Cunninghamia lanceolata Hooker) and Taiwania (Taiwaniacryptomerioides Hay.). Q J Chin For 21:45-72

Hu HT (2002) Glomus spinosum sp. nov. in the Glomaceae from Taiwan. Mycotaxon 83:159-164

Ingham ER, Wilson MV (1999) The mycorrhizal colonization of six wetland plant species at sites differing in land use history. Mycorrhiza 9:233-235

Janos DP (1980) Vesicular-arbuscular mycorrhizae affect lowland tropical rain forest plant growth. Ecology 61:151-162

Jansa J, Mozafar A, Anken T, Ruh R, Sanders IR, Frossard E (2002) Diversity and structure of AMF communities as affected by tillage in a temperate soil. Mycorrhiza 12:225-234

Johnson NC, Tilman D, Wedin D (1992) Plant and soil controls on mycorrhizal fungal communities. Ecology 73:2034-2042
Klironomos JN, Hart MM, Gurney JE, Moutoglis P (2001) Interspecific differences in the tolerance of arbuscular mycorrhizal fungi to freezing and drying. Can J Bot 79:1161-1166

Li Y, Wang B (1999) A preliminary report on the VA mycorrhizal fungi infecting Mimosa padica. J Xian United Univ 2:32-34

Li T, Zhao ZW (2005) Arbuscular mycorrhizas in a hot and arid ecosystem in southwest China. Appl Soil Ecol 29:135-141

Li T, Li JP, Zhao ZW (2004) Two new records of arbuscular mycorrhizal fungi in China. Mycosystema 23:144-145

Lin XG, Hao WY (1989) The dependency of different plants on vesicular-arbuscular mycorrhizal fungi. Acta Bot Sinica 31: $721-725$

Liu RJ, Xue BY, Huang Z (1987) Investigation of vesiculararbuscular (VA) mycorrhiza in the fruit of Shandong Province. J Shandong Agric Univ 18:25-31

Liu YR, Fang YC, Huang Z (2001) Isolation and identification of vesicular arbuscular mycorrhizal fungi in the tobacco culture area in Shandong province. J Jilin Agric Univ 23:40-45

Liu RJ, Wang FY, Meng XX (2002) Arbuscular mycorrhizal fungi on the islands of Bohai Bay. Mycosystema 21:525-532

Morton JB, Redecker D (2001) Two new families of Glomales, Archaeosporaceae and Paraglomaceae, with two new genera Archaeospora and Paraglomus, based on concordant molecular and morphological characters. Mycologia 93:181-195

Muthukumar T, Udaiyan K (2000) Arbuscular mycorrhizas of plants growing in the Western Ghats region, southern India. Mycorrhiza 9:297-313

Muthukumar T, Sha LQ, Yang XD, Cao M, Tang JW, Zheng Z (2003) Mycorrhiza of plants in different vegetation types in tropical ecosystems of Xishuangbanna, southwest China. Mycorrhiza 13:289-297

Muthukumar T, Udaiyan K, Shanmughavel P (2004) Mycorrhiza in sedges: an overview. Mycorrhiza 14:65-77

Newman EI, Reddell P (1987) The distribution of mycorrhizas among families of vascular plants. New Phytol 106:745-751

Niu JQ (1994) A survey of vesicular-arbuscular mycorrhiza in Guangdong province and its application study. Acta Pedol Sinica 31:54-63

O'Connor PJ, Smith SE, Smith AF (2002) Arbuscular mycorrhizas influence plant diversity and community structure in a semiarid herbland. New Phytol 154:209-218

Pan XL, Zhang GY, Wang YJ, Wu SJ (1997a) A new VAM species from the loess plateau, Scutellospora trirubiginopa. Mycosystema 16:169-171

Pan XL, Zhang GY, Wang YJ, Wu SJ (1997b) VAMF species of the loess plateau IV. Mycosystema 16:166-168

Peng SB, Shen CY, Chiu WF (1990) Some Endogonaceae mycorrhizal fungi from China. Acta Mycol Sinica 9:169-175

Qiao HQ, Zhang Y, Guo LD, Fu JF (2005) Arbuscular mycorrhizal fungi associated with the most common plants in north Xinjiang. Mycosystema 24:130-136

Redecker D, Hijri I, Wiemken A (2003) Molecular identification of arbuscular mycorrhizal fungi in roots: perspectives and problems. Folia Geobot 38:113-124

Rickerl DH, Sancho FO, Ananth S (1994) Vesicular-arbuscular endomycorrhizal colonization of wetland plants. J Environ Qual 23:913-916

Sanders IR, Clapp JP, Wiemken A (1996) The genetic diversity of arbuscular mycorrhizal fungi in natural ecosystems: a key to understanding the ecology and functioning of the mycorrhizal symbiosis. New Phytol 133:123-134

Schüßler A, Schwarzott D, Walker C (2001) A new fungal phylum, the Glomeromycota: phylogeny and evolution. Mycol Res 105: 1413-1421

Shi ZY, Chen YL, Liu RJ (2003a) Arbuscular mycorrhizal fungi of Dipterocarpaceae in Xishuangbanna, southern Yunnan. Mycosystema 22:402-409

Shi ZY, Chen YL, Liu RJ (2003b) Arbuscular mycorrhizal fungi of Dipterocarpaceae on Jianfengling Mountain, Hainan Province. Mycosystema 22:211-215

Shi ZY, Chen YL, Liu RJ (2004) A new species record of arbuscular mycorrhizal fungi in China. Mycosystema 23:312 
Smith SE, Read DJ (1997) Mycorrhizal symbiosis, 2nd edn. Academic Press, London, p 605

Stutz JC, Copeman R, Martin CA, Morton JB (2000) Patterns of species composition and distribution of arbuscular mycorrhizal fungi in arid regions of southwestern North America and Namibia, Africa. Can J Bot 78:237-245

Tang ZY (1977) Citrus mycorrhiza. Citrus Sci Technol 3:73

Tang ZJ, Zang M (1984) A supplement to the manual of Endogonaceae and a new species, Glomus citricolum. Acta Bot Yunnanica 6:295-304

Tester M, Smith SE, Smith FA (1987) The phenomenon of 'nonmycorrhizal' plants. Can J Bot 65:419-431

Trappe JM (1987) Phylogenetic and ecologic aspects of mycotrophy in the angiosperms from an evolutionary standpoint. In: Safir GR (ed) Ecophysiology of VA mycorrhizal plants. CRC Press, Boca Raton, pp 5-26

Walker C, Schüßler A (2004) Nomenclatural clarifications and new taxa in the Glomeromycota. Mycol Res 108:979-982

Wang GM (1985) Soil pH and vesicular-arbuscular mycorrhizas. In: Fitter AH (ed) Ecological interactions in soil. Blackwell, Oxford, pp 219-224

Wang GM (1993) Effect of pH on arbuscular mycorrhiza. I. Field observation on the long term liming experiments at Rothamsted and Woburn. New Phytol 124:465-472

Wang P, Hu ZJ (1989) The isolation and identification of vesiculararbuscular mycorrhizal fungi on cotton. J Huazhong Agric Univ 8:36-44

Wang FY, Liu RJ (2002) Arbuscular mycorrhizal fungi in salinealkaline soils of the Yellow River Delta. Mycosystema 21: 196-202

Wang HG, Wu GY, Li HQ (1992) Discovery of a species Sclerocystis sinuosa - on Endogonaceae in China. Acta Mycol Sinica 11:78-79

Wang YS, Zhang MQ, Xing LJ, Wang KN (1996) VA mycorrhizal fungi from the south and east coasts of China. I. Four species of Sclerocystis. Acta Mycol Sinica 15:161-165

Wang Q, Li HQ, Du YR, Lin Y, Li HW (1998a) Isolation and identification of VA mycorrhizal fungi on Radix gentianae. Biotechnology 8:19-22

Wang YS, Zhang MQ, Wang KN, Xing LJ (1998b) VA mycorrhizal fungi of the south and east coasts of China IV, four new records. Mycosystema 17:301-303

Wang FY, Liu RJ, Lin XG, Zhou JM (2003) Comparison of diversity of arbuscular mycorrhizal fungi in different ecological environments. Acta Ecol Sinica 23:2666-2671

Wang FY, Lin XG, Zhou JM (2004a) Biodiversity of AMF in China. Chin J Ecol 23:149-154

Wang MY, Diao ZK, Liu RJ (2004b) Taxonomic characteristics and distribution of species and genera in Gigasporaceae of AMF. J Fungal Res 2:6-11

Wu CG, Chen ZC (1986) The Endogonaceae of Taiwan. I. A preliminary investigation on Endogonaceae of bamboo vegetation at Chitou areas, central Taiwan. Taiwania 31:65-87

Wu CG, Chen ZC (1987) The Endogonaceae of Taiwan. II. Two new species of Sclerocystis from Taiwan. Trans Mycol Soc Rep China 2:73-83

Wu TH, Hao WY, Lin XG, Shi YQ (1994) Two new records of VA mycorrhizal fungi from China. Acta Mycol Sinica 13:310-311

Wu TH, Hao WY, Lin XG, Shi YQ (1995a) VA mycorrhizal fungi (Glomales) and their ecological distribution in red soils. Acta Mycol Sinica 14:81-85

Wu CG, Liu YS, Hwuang L (1995b) Glomales of Taiwan. V. Glomus chimonobambusae and Entrophospora kentinesis spp. nov. Mycotaxon 53:283-294

Wu CH, Tang M, Ma YS, Li XL (2000) Five species of AMF from the rhizal soil of Abies fargesii Franch forest in Taibai Mountain Reserve. J Northwest For Univ 15:49-52

Wu CH, Wang JR, Yang JX, Liu LH (2001) A study on the resources of AMF in Taibai Mountain Nature Preserve. J Northwest For Univ 16:35-39
Xing XK, Li Y, Dalpe Y (2000) Ten species of VAMF in five ginseng fields of Jilin province. J Jilin Agric Univ 22:41-46

Yang L, Wang GH, Ren LC, Zhao ZW (2002) Arbuscular mycorrhizae of the family Amaranthaceae. Acta Bot Yunnanica 24:37-40

Yang AN, Li LF, Zhao ZW (2004) A new record species of arbuscular mycorrhizal fungi in China. Mycosystema 23:603604

Yi WM, Ding MM (1990) A preliminary survey of vesiculararbuscular mycorrhiza associated with common plants in the plantations at Heshan and Dianbai, Guangdong Province. Trop Subtrop For Ecosyst 7:41-50

Zhang MQ, Wang YS (1991a) A key to the species in Glomus. Microbiology 18:367-371

Zhang MQ, Wang YS (1991b) Seven species of VA mycorrhizal fungi from northern China. Acta Mycol Sinica 10:13-21

Zhang MQ, Wang YS, Huang L (1992) Eight species of VA mycorrhizal fungi from northern China. Acta Mycol Sinica 11:258-267

Zhang MQ, Wang YS, Zhang C, Huang L (1994) The ecological distribution characteristics of some genera and species of VAMF in northern China. Acta Mycol Sinica 13:166-172

Zhang MQ, Wang YS, Wang KN, Xing LJ (1996) The VA mycorrhizal fungi of the southeast coastal areas of China. II. Four species of Glomus. Mycosystema 15:241-246

Zhang MQ, Wang YS, Xing LJ (1997) Glomus dolichosporum, a new species of Glomales from southern China. Mycosystema $16: 241-243$

Zhang MQ, Wang YS, Wang KN, Xing LJ (1998a) VA mycorrhizal fungi of the south and east coasts of China, seven new records of Acaulospora. Mycosystema 17:15-18

Zhang MQ, Wang YS, Xing LJ (1998b) The ecological distribution of AM fungal communities in the south and east coasts of China. Mycosystema 17:274-277

Zhang MQ, Wang YS, Xing LJ (1999) The regional distribution of AMF in the south and east coasts of China. Mycosystema $18: 145-148$

Zhang MQ, Wang YS, Xing LJ, Zhang WM, Ma YQ, Li XP (2001) Three new records of Acaulospora from an aluminum mine field in Guangxi province in China. Mycosystema 20:271-272

Zhang Y, Guo LD, Liu RJ (2003a) Diversity and ecology of arbuscular mycorrhizal fungi in Dujiangyan. Acta Phytoecol Sinica 27:537-544

Zhang Y, Guo LD, Liu RJ (2003b) Arbuscular mycorrhizal fungi associated with the most common plants in the subtropical region of Dujiangyan. Mycosystema 22:204-210

Zhang Y, Guo LD, Liu RJ (2004a) Arbuscular mycorrhizal fungi associated with common pteridophytes in Dujiangyan, southwest China. Mycorrhiza 14:25-30

Zhang Y, Guo LD, Liu RJ (2004b) Survey of arbuscular mycorrhizal fungi in deforested and natural forest land in the subtropical region of Dujiangyan, southwest China. Plant Soil 261: 257-263

Zhao ZW (1998) VA mycorrhizal fungi in the rhizosphere soil of tropical and subtropical pteridophytes in Yunnan. Acta Bot Yunnanica 20:183-192

Zhao ZW (2000) The arbuscular mycorrhizas of pteridophytes in Yunnan, southwest China: evolutionary interpretations. Mycorrhiza 10:145-149

Zhao ZW, Du G (1997) Six species of VA mycorrhizal fungi from the rhizosphere of pteridophytes in Yunnan. Mycosystema $16: 208-211$

Zhao ZW, Li XW, Wang GH, Cheng LZ, Sha T, Yang L, Ren LC (2001a) AMF in the tropical rain forest of Xishuangbanna. Mycosystema 20:316-323

Zhao ZW, Qin XZ, Li XW, Cheng LZ, Sha T, Wang GH (2001b) Arbuscular mycorrhizal status of plants and the spore density of arbuscular mycorrhizal fungi in the tropical rain forest of Xishuangbanna, southwest China. Mycorrhiza 11:159-162

Zhao ZW, Ren LC, Li T, Li JP (2003) Arbuscular mycorrhizas in the dry hot valley of Jinsha River. Acta Bot Yunnanica 25:199-204 